\title{
Styloglossus Muscle
}

National Cancer Institute

\section{Source}

National Cancer Institute. Styloglossus Muscle. NCI Thesaurus. Code C53071.

A small muscle of the tongue, which originates from the styloid process and inserts on to the side of the tongue; it functions to elevate and retract the tongue. 